\title{
Coping Kecemasan Siswa SMA dalam Menghadapi Ujian Tulis Berbasis Komputer (UTBK) Tahun 2019
}

\author{
Mulia Mukminina ${ }^{1}$, Zaenal Abidin ${ }^{1}$ \\ ${ }^{1}$ Fakultas Psikologi, Universitas Padjadjaran, \\ Jl. Raya Bandung Sumedang KM 21, Jatinangor - Sumedang, Jawa Barat \\ Penulis untuk korespondensi/E-mail : muliamnina@gmail.com
}

\begin{abstract}
Abstrak - Tahun 2019 Kemenristekdikti memberlakukan kebijakan baru dalam seleksi penerimaan mahasiswa baru, yakni Ujian Tulis Berbasis Komputer (UTBK). Pada tahun ini peserta akan mengikuti UTBK terlebih dahulu kemudian nilai yang didapatkan akan dipakai untuk mendaftar ke perguruan tinggi. Jika dilihat dari peminatnya dari tahun ke tahun serta keterbatasan Perguruan Tinggi Negeri (PTN) dalam menerima mahasiswa baru, terdapat persentase cukup tinggi terkait peserta yang gagal diterima di PTN. Fakta ini dapat memunculkan kecemasan pada siswa SMA yang disebabkan oleh beberapa hal, yakni rasa tidak percaya diri dalam menghadapi tes, khawatir terhadap saingan, dan tidak yakin dengan kemampuan diri. Meskipun begitu, siswa yang memiliki kecemasan dalam menghadapi UTBK tentu memiliki strategi coping masing-masing. Dengan demikian, penelitian ini bertujuan untuk melihat gambaran coping kecemasan pada siswa SMA yang mengadapi UTBK tahun 2019. Metode yang digunkan adalah metode kualitatif dengan pendekatan studi deskriptif. Teknik pengambilan data dilakukan melalui screening dan interview, kemudian hasilnya akan diolah menggunakan analisis tematik. Hasil penelitian menunjukkan pada siswa SMA yang memiliki tingkat kecemasan mild dalam menghadapi UTBK tahun 2019 cenderung memiliki teknik coping kecemasan yang tergolong adaptif. Coping tersebut dominan melibatkan kognitif, seperti problem solving, managing avoidance, challenging anxious thoughts. Sedangkan pada siswa perempuan, coping juga melibatkan emosi, yakni berdoa.
\end{abstract}

Abstract - In 2019, Kemenristekdikti will legitimate a new policy about the admission of new state university students, which is a computerized based test called UTBK. The students will attend the UTBK first and the score will be used to be their tickets to apply to the state university. Based on the data, it seems that the universities themselves have a limitation on accepting new students, therefore it might cause a huge percentage of students who fail attending university. This fact might be caused anxiety towards students who will face UTBK this year. According to that possibility, the assumption is every student who has anxiety will have different types of coping strategies with their anxiety. Thus, this research aims to describe how the students cope with their anxiety within this circumstance. The method that is used in this research is the qualitative method with a descriptive approach. The data was collected using screening and interview, then it was being analyzed using thematic analysis. The result has shown that most of the students who have a mild level of anxiety have an adaptive coping strategy. Most of them involve their cognitive, such as problem-solving, managing avoidance, and challenging anxious thoughts, while on girl students the finding showed the technique also involved physics and emotion, which is praying.

Keyword - Anxiety, Coping anxiety, High school students

\section{PENDAHULUAN}

K ementrian Riset, Teknologi dan Pendidikan Tinggi (Kemenristekdikti) telah menetapkan kebijakan terkait Seleksi Masuk Perguruan Tinggi Negeri Tahun 2019. Kebijakan tersebut berisikan tentang pengembangan model dan proses seleksi mahasiswa baru yang berstandar nasional serta sesuai dengan perkembangan teknologi informasi di era digital. Mulai tahun 2019 Kemenristekdikti akan memberlakukan kebijakan di bidang seleksi penerimaan mahasiswa baru tersebut yang dilaksanakan oleh institusi bernama Lembaga Tes Masuk Perguruan Tinggi (LTMPT). 
LTMPT ini memiliki salah satu tanggung jawab yakni mengatur dan mengolah pelaksanaan Ujian Tulis Berbasis Komputer (UTBK). Pelaksanaan UTBK sendiri akan sedikit berbeda, jika sebelumnya peserta daftar terlebih dahulu lalu kemudian mengikuti tes, tahun ini peserta akan tes terlebih dahulu kemudian nilai yang didapatkan akan dipakai untuk mendaftar ke perguruan tinggi. Sedangkan metode yang digunakan dalam UTBK ini tentu menggunakan metode tes berbasis komputer dengan Android yang masih dalam persiapan.

Selain dari perubahan tersebut, pola seleksi masuk PTN tetap sama, yakni akan dilaksanakan melalui 3 jalur SNMPTN, SBMPTN dan Ujian Mandiri. Daya tampung SNMPTN minimal 20\%, SBMPTN minimal 40\% dan Seleksi Mandiri maksimal 30\% dari kuota daya tampung tiap prodi di PTN. Jika dilihat dari peminatnya dari tahun ke tahun, tiap PTN hanya dapat menerima jumlah yang amat terbatas. Hal tersebut menyebabkan tiap tahun terdapat perbedaan prosentase yang besar terkait peserta yang diterima di PTN dengan peserta yang gagal, terutama yang mengikuti SBMPTN. Sebagai contoh, data menyebutkan terdapat $81,3 \%$ peserta yang gagal dalam SBMPTN di tahun 2013 [1], kemudian $84,2 \%$ di tahun 2014 [2]. Terakhir, 80,7\% di tahun 2018 kemarin [3].

Prosentase peserta yang gagal melalui jalur SBMPTN ditiap tahunnya ini salah satunya disebabkan karena terjadinya peningkatan jumlah peserta. Biasanya dikarenakan terdapat peserta yang telah gagal sebelumnya kemudian kembali mengikuti SBMPTN di tahun berikutnya. Fakta ini tentu memunculkan kecemasan pada siswa SMA kelas 3 yang akan segera lulus dan melanjutkan pendidikan ke perguruan tinggi [4]. Kecemasan ini muncul dikarenakan beberapa hal salah satunya rasa tidak percaya diri dalam menghadapi tes [5] khawatir melihat saingan dengan nilai yang lebih tinggi [6] dan tidak yakin dengan kemampuan yang dimiliki [7].

Mengutip penjelasan American Psychology Association, kecemasan merupakan sebuah insting alami yang dimiliki individu untuk melawan atau pergi (fight or flight) dalam merespon sebuah ancaman atau bahaya. Memiliki kecemasan itu normal, kecuali ketika kecemasan tersebut telah mengganggu kehidupan sehari-hari [8]. Kecemasan menyebabkan banyak kerugian, salah satunya dapat menghambat dalam berpikir dan menghasilkan problem solving. Cambridgeshire dan
Peterborough [9] menjaskan bahwa kecemasan memiliki 4 komponen, yakni fisik, pikiran, perasaan, dan perilaku. Semakin parah kecemasan seseorang maka akan semakin parah pula gejala-gejala yang muncul pada keempat komponen tersebut.

Berdasarkan pemaparan tersebut, sebuah kecemasan tentu perlu untuk diatasi agar tidak mengganggu optimalitas siswa dalam mempersiapkan diri mengikuti berbagai tes, khususnya UTBK. Maka, tentu tiap siswa memiliki caranya sendiri untuk mengatasi kecemasannya tersebut. Upaya-upaya untuk mengatasi kecemasan biasa disebut juga dengan coping anxiety. Coping anxiety tentu bermacam-macam. Salah satunya, adalah dengan mengolah dan menurunkan ketidaknyamanan pada komponen kecemasan yang terganggu.

Dennis Greenberger \& Christine Padesky [8] menjelaskan coping anxiety yang dapat dilakukan menyasar pada komponen yang terganggu akibat kecemasan itu sendiri. Pertama, komponen fisik ; control breathing, progressive muscle relaxation, dan reduce caffeine intake. Kedua, komponen pikiran dan emosi; challenging anxious thoughts, controlled worry period, dan problem solving. Ketiga, komponen perilaku ; managing avoidance. Teknik coping anxiety ini dapat dilakukan guna mengurangi gejala-gejala yang muncul di tiap komponen kecemasan.

Sebuah metode atau teknik coping seperti dijelaskan diatas dapat digolongkan sebagai coping yang adaptif. Coping adaptif ini dapat memeberikan pengaruh positif kepada individunya, yakni mampu meningkatlkan fungsi individunya. Misalnya, meningkatkan kemampuan memecahkan masalah, meregulasi emosi yang dirasa, mengekspresikan emosi, berpikir lebih positif, dan menerima diri sendiri [10]. Sedangkan coping yang maladaptif biasanya memberikan pengaruh sebaliknya. Pergi atau menghindari situasi atau kejadian yang menjadi sumber kecemasan sebagai coping yang diambil secara terus menerus dapat memperburuk kecemasan itu sendiri [11].

Namun demikian, teknik coping anxiety yang dipilih dan dilakukan oleh siswa serta dampaknya pada tingkat kecemasannya tentu dapat berbeda dengan teori. Maka dari itu, peneliti bermaksud untuk mengungkap gambaran coping kecemasan yang dilakukan oleh siswa dengan tingkat kecemasan tertentu dalam menghadapi UTBK tahun 2019. 


\section{METODE}

\section{Desain Penelitian}

Partisipan yang akan menjadi responden dalam penelitian ini adalah siswa/siswi SMA berusia 17-18 tahun yang akan menghadapi UTBK di tahun 2019. Responden sendiri dipilih berdasarkan hasil dari screening kecemasan terlebih dahulu menggunakan kuesioner kecemasan yakni Hamilton Anxiety Rating Scale (HAM-A) [12]. Kemudian, dari seluruh partisipan yang mengikuti screening kecemasan, akan dipilih sebanyak 3 orang untuk dijadikan responden. Ketiga responden tersebut berasal dari katagori level atau tingkat kecemasan yang paling sering muncul dari seluruh partisipan yang mengikuti screening tersebut agar dapat memberikan gambaran yang lebih akurat terkait coping kecemasan siswa.

\section{Teknik Pengambilan Data}

Leedy [13] menyatakan bahwa metodologi penelitian mengacu pada pendekatan umum yang diambil peneliti dalam melakukan sebuah penelitian. Berdasarkan hal tersebut, peneliti menggunakan metode kualitatif dengan pendekatan studi deskriptif, dimana pendekatan ini dirasa mampu menggali data lebih dalam lagi terkait pandangan dan perilaku individu [14]. Oleh karena itu, pendekatan ini dapat memberikan apa yang dibutuhkan dalam mencapai tujuan dari penelitian, yakni memperoleh gambaran terkait coping kecemasan yang dilakukan oleh siswa SMA dalam menghadapi UTBK tahun 2019. Metode pengumpulan data dalam penelitian ini menggunakan interview yang mengacu pada guideline yang telah disusun terlebih dahulu. Guideline interview ini disusun berdasarkan teori cognitive behavioral therapy dalam mengatasi kecemasan yang dikembangkan oleh Greenberger dan Padesky [8].

\section{Teknik Analisis Data}

Dalam penelitian studi deskriptif ini, data yang diperoleh melalui interview dianalisis menggunakan analisis tematik. Analisis tematik dilakukan dengan menentukan tema-tema yang didapat dari jawaban yang diberikan oleh responden. Kemudian, tema yang telah terkumpul tersebut dikelompokkan ke dalam komponen-komponen coping kecemasan yang mengacu pada kerangka teori sekaligus memaparkan penemuan-penemuan baru. Dengan demikian, hasil analisis dapat secara jelas menggambarkan fenomena serta karakteristik yang mengikutinya [15].

\section{Validasi}

Dalam penelitian ini, untuk menjaga agar hasil data yang diperoleh terinterpretasi tanpa bias, maka peneliti menggunakan teknik review yang dilakukan dengan meminta peneliti lain untuk mengevaluasi seluruh hasil data serta coding yang telah dilakukan oleh peneliti. Dengan demikian, diharapkan hasil akhir tersebut terbebas dari pengaruh motivasi atau penilaian peneliti pribadi.

\section{HASIL DAN PEMBAHASAN}

Berdasarkan data yang didapat dari hasil screening kecemasan pada 20 siswa SMA kelas 3 yang menghadapi UTBK, diperoleh sebanyak 13 siswa (65\%) memiliki tingkat kecemasan mild atau ringan, 4 siswa (20\%) moderate atau sedang, dan 3 siswa $(15 \%)$ severe atau berat (lihat grafik 1$)$.

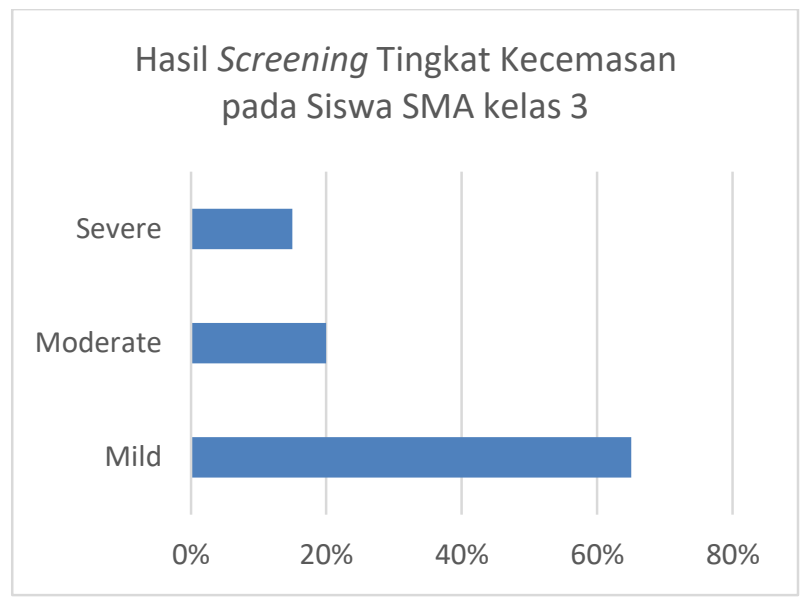

Grafik 1. Prersentase hasil screening tingkat kecemasan yang dialami siswa SMA kelas 3 dalam Menghadapi UTBK tahun 2019

Dari hasil tersebut dapat dilihat bahwa mayoritas siswa memiliki tingkat kecemasan mild, maka peneliti memilih secara acak 3 orang dari siswa dengan tingkat kecemasan tersebut untuk kemudian diwawancarai lebih lanjut. Dengan demikian siswasiswa tersebut dapat merepresentasikan gambaran secara umum kondisi kecemasan siswa dan bagaimana cara mengatasinya. 
Tabel 1. Teknik coping yang digunakan oleh siswa kelas 3 SMA dengan tingkat kecemasan mild

\begin{tabular}{|c|c|c|}
\hline Subjek & $\begin{array}{c}\text { Sumber } \\
\text { Komponen } \\
\text { Kecemasan }\end{array}$ & $\begin{array}{c}\text { Teknik Coping } \\
\text { Kecemasan }\end{array}$ \\
\hline Laki-laki & Kognitif & 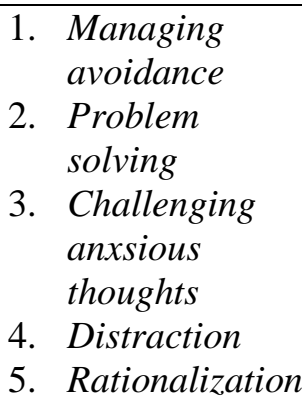 \\
\hline Perempuan & Kognitif & $\begin{array}{ll}\text { 1. } & \text { Self-talk } \\
\text { 2. } & \text { Distraction } \\
\text { 3. } & \text { Rationalization } \\
\text { 1. } & \text { Ritual religi }\end{array}$ \\
\hline
\end{tabular}

Setelah diwawancari, pada Tabel 1 menunjukkan bahwa terdapat berbagai cara yang biasa digunakan oleh siswa dengan tingkat kecemasan mild ini dalam menghadapi kecemasannya, baik saat akan menghadapi UTBK maupun sesudahnya. Pertama, teknik coping kecemasan yang cenderung ditemui hanya pada siswa laki-laki adalah managing avoidance, yakni teknik mengatur penghindaran sumber kecemasan dalam beberapa waktu tertentu untuk kemudian bisa kembali dengan pikiran dan perasaan yang lebih baik. Teknik ini dilakukan dengan cara yang relatif serupa, dimana mereka cenderung memusatkan pikiran pada tes yang terdekat terlebih dahulu, sehingga pemikiran yang menjadi sumber kecemasan terkait UTBK dapat terkesampingkan. Hal itu diungkapkan oleh Subjek 3 ketika ditanyakan bagaiman ia bisa tidak mencemaskan UTBK di hari-hari sebelum tes tersebut dilaksanakan,"Mikirinnya yang USBN sama UNBKnya aja dulu.." Demikian jawaban subjek tersebut.

Usaha memprioritaskan masalah terdekat ternyata cukup membantu siswa laki-laki dalam menghindari pikiran cemas akan UTBK dalam kurun waktu tertentu, sehingga kecemasan terkait hal tersebut tidak terlalu mendominasi waktunya. Selanjutnya, pada siswa laki-laki mereka juga menggunakan tidur sebagai cara untuk menghindari pikiran yang terganggu karena kecemasan yang dirasakan. Hal ini ditunjukkan oleh pernyataan dari Subjek 2, "jadi kalo bener-bener gak bisa pas ngerjain pas...belajar, udah mentok banget, yaudah aku tidur, temen-temen aku juga pada gitu. Nah tapi biasanya abis tidur tuh kayak ke recall lagi gitu loh materi-materi pelajarannya, jadi malah bisa jawab pertanyaan yang gak bisanya." Dari pernyataan tersebut dapat dipahami bahwa teknik ini membantu subjek untuk kembali berpikir tenang sehingga dapat mengerjakan ujian dengan lebih tenang. Namun demikian, teknik serupa tidak ditemukan pada siswa perempuan.

Kedua, teknik problem solving pun cenderung banyak ditemukan pada siswa laki-laki. Hal ini kemungkinan besar disebabkan oleh komponen kecemasan yang dirasakan oleh siswa laki-laki adalah bersumber pada pikirannya. Maka dari itu, teknik ini dilakukan dengan cara menyelesaikan kecemasannya dengan berfokus pada solusi. Terdapat beberapa cara, yakni membuat rencana untuk menenangkan diri, membuat strategi dalam menyelesaikan permasalahan yang menjadi sumber kecemasan, serta membuat persiapan yang lebih lama dan matang untuk menghindari kecemasan yang mungkin akan terjadi di masa yang akan datang. Hal-hal tersebut dapat dibuktikan dengan salah satu pernyataan subjek 2 yakni, "aku sih planningnya chill aja karena aku udah nyicil dari lama kan. Emang punya plan dari liburan naik kelas 3 tuh udah mulai nyicil soal gitu..".

Pernyataan dari Subjek 3 pun serupa, dimana ia memfokuskan kepada strategi yang diyakininya untuk menghindari kecemasan yang mungkin akan terjadi saat tes, yakni "aku inget kata guru SMA aku dulu, pokoknya isi aja dulu semuanya, nanti itungnya belakangan. Soalnya UTBK tuh udah gak ada mines-minesnya lagi, jadi jangan sampe ada yang gak keisi.". Dari kedua pernyataan tersebut dapat tergambar bahwa pada siswa laki-laki mereka mencoba mengatasi kecemasannya dengan membuat perencanaan atau strategi tertentu untuk menghadapi UTBK, yang kemudian hal tersebut ia ingat-ingat selalu bilamana pikiran cemasnya muncul baik ketika mendekati hari tes maupun saat mengerjakan tes nanti.

Selanjutnya, teknik coping kecemasan yang dilakukan oleh baik siswa laki-laki maupun perempuan adalah challenging anxious thoughts. Teknik ini dilakukan dengan menantang pikiran negatif, dengan megidentifikasi situasi, mengidentifikasi pikiran yang salah, dan bagaimana pikiran itu bisa mempengaruhi perasaanya. Teknik ini dilakukan dengan cara yang berbeda-beda.

Pada siswa laki-laki, mereka cenderung mencoba untuk mengidentifikasi pikiran apa yang membuatnya cemas, kemudian mencoba untuk 
mengidentifikasi pemikiran apa yang sekiranya akan membuatnya merasa lebih baik. Dengan demikian pemikiran baru yang lebih positif tersebut bisa menggantikan pemikiran cemas mereka, hingga perasaannya pun lebih baik. Hal ini dibuktikan dengan pernyataan, "Aku anggep kalo kayak gitu.. Kayak misalnya aku ngerasa cemas-cemas kayak gitu yaa. Gimana ya. Aku anggep yaa itu biasa aja gitu. Orang-orang juga ngalamin itu. Jadi kalo aku salah yaa mereka juga bisa salah. Jadi yaa gitu aja gak usah takut-takut amat kalo aku salah-salah jawab nanti gitu, yaudah aja dibawa santai..”.

Sedangkan untuk siswa perempuan, ia cenderung memilih melakukan self-talk untuk menentang pikiran negatif dengan memotivasi dirinya sendiri. Hal ini dapat ditemukan pada jawaban subjek 1, yakni "Terus biasanya $R$ juga ngaca sambil ngomong sama diri sendiri kalo R pasti bisa. " Selain itu, pada siswa perempuan juga ditemukan relaxation berupa cuci muka pada pernyataanya, yakni "R pergi ke toilet bu. Waktu itu sampe 2 kali, cuci muka biar gak ngantuk terus biar semangat lagi..". Pernyataan tersebut menunjukkan usaha yang dilakukan untuk mengurangi gejala kecemasan yang dirasakan secara fisik, yakni mengantuk akibat lelah karena cemas dalam waktu yang lama.

Jika mengacu kepada penjelasan Greenberger [8] cuci muka, olah raga, mengatur nafas, dan lain sebagainya merupakan salah satu upaya untuk merelaksasikan kondisi fisik yang mungkin terganggu karena kecemasan yang dirasakan. Ia juga menjelaskan biasanya komponen kecemasan fisik akan lebih baik diatasi dengan melakukan suatu usaha fisik juga. Seperti pemanasan atau exercise, olahraga, atau sesederhana relaksasi pernafasan.

Terakhir, adapun penemuan baru yang ditemukan pada siswa laki-laki dan perempuan dalam mengatasi kecemasannya adalah distraction, rasionalization, dan ritual religi. Penemuan pertama, teknik distraction dilakukan lebih banyak oleh siswa laki-laki dimana mereka memilih bermian game, ngobrol atau sharing dengan teman, atau nonton tv. Hal ini dapat dibuktikan dari pernyataan Subjek 2, “ Iya biasanya main game atau nonton youtube, nonton apaan aja. Biar.. gak cemas-cemas banget.".

Tergambar bahwa pada siswa laki-laki, mengalihkan pikiran cemas terkait UTBK dengan nonton tv dan bermain game yang tentunya tidak berkaitan dengan belajar atau hal-hal yang dapat mengingatkannya pada UTBK membuatnya merasa lebih tidak cemas.

Upaya penghindaran kecemasan dengan cara ini dapat dikatakan kurang adaptif. Hal ini sebetulnya tidak terlalu menyimpang atau dapat dikatakan maladaptif selama dilakukan masih dalam batasan normalnya. Namun demikian, jika coping ini dilakukan terus menerus tanpa upaya lainnya maka dapat dikatakan coping ini maladaptif. Adapun coping kecemasan yang dapat dikatakan tidak adaptif seperti pada hasil studi Piekarska [16] kepada siswa laki-laki SMA, adalah pergi atau kabur dari masalah, membully teman yang lain, dan menghilang ketika mereka menghadapi situasi yang menimbulkan stress.

Pada siswa perempuan, ia pun melakukan upaya mendistraksi diri dari kecemasan yakni dengan mengobrol dengan temannya. Menurut Thenga [16] mencari dukungan sosial dengan berbagi cerita atau sekedar mengobrol dengan teman merupakan salah satu coping kecemasan yang biasa dilakukan oleh para remaja, khususnya perempuan. Hal ini disebabkan karena untuk sebagian siswa perempuan, perasaan cemas muncul ketika mereka terlalu berfokus pada permasalahan, itu sebabnya jika permasalahan tersebut ia lupakan untuk sementara waktu atau ia bagikan dengan orang lain kemudian ia mendapat dukungan positif sebagai feedback, maka mereka pun merasa lebih baik dan siap menghadapi permasalahan tersebut.

Selanjutnya, penemuan kedua yakni teknik rasionalization yang lebih banyak digunakan oleh siswa laki-laki dari pada perempuan. Teknik ini dilakukan dengan mencoba untuk bersikap relaistis dan melumrahkan segala kemungkinan yang akan terjadi, sehingga ia merasa pikirannya lebih tenang. Seperti yang dinyatakan oleh Subjek 2, "Kayak gak usah terlalu dipikirin, karena masih ada hal lain kok, itu bukan akhir dari segalanya." Pada pernyataan tersebut nampak bahwa pada siswa lakilaki, dikarenakan komponen kecemasan bersumber pada pikirannya sendiri, maka salah satu cara yang dilakukan untuk mengatasinya pun dengan membangun pemikiran yang rasional atau masuk akal untuk mengurangi kecemasannya tersebut.

Terkhir, penemuan teknik coping yang muncul hanya pada siswa perempuan adalah ritual religi, yakni berdoa. Ini dapat dibuktikan dengan pernyatan Subjek 1, yakni "Terus udah gitu baca doa aja biar makin tenang,". Dari pernyataan tersebut tergambar 
bahwa pada siswa perempuan, komponen kecemasannya bersumber dari emosi. Dengan demikian, salah satu coping kecemasan yang ia coba untuk lakukan pun berkaitan dengan menenangkan emosinya, yakni berdoa.

Berdoa merupakan ritual agama yang dilakukan sebagai teknik coping dalam upaya menimbulkan ketenangan batin. Penemuan ini serupa dengan hasil penelitian Pragement [17] dimana penelitinya mengkonfirmasi bahwa ritual agama memiliki hubungan yang erat dalam aspek coping baik stress maupun kecemasan. Mereka pun menambahkan bahwa berdoa atau shalat merupakan strategi terkuat dalam coping, terutama pada remaja yang memiliki kecenderungan tingkat religiusitas yang tinggi. Keyakinan bahwa terdapat Tuhan yang menjadi tempat bersandar atas segala urusan di dunia, mampu mengundang kedamaian tersendiri bagi yang mempercayainya. Dari penelitian Pragament [17] pun dikutip bahwa siswa yang memiliki keluarga dengan tingkat pelaksanaan ibadah atau ritual agama yang tinggi memiliki kecenderungan coping maladaptif yang kecil. Ini bermakna bahwa siswa yang mendapatkan pemahaman religi yang baik cenderung mencari strategi coping yang sesuai dan tidak menyimpang.

Berdasarkan pemaparan penjelasan di atas, dapat tergambarkan bahwa cara siswa SMA melakukan coping kecemasan bermacam-macam, tergantung pada komponen kecemasan yang muncul, baik itu pada fisik, pikiran, emosi, maupun perilakunya. Dapat dipahami pula, jenis coping kecemasan yang tepat dan sesuai menyasar pada sumber kecemasannya mampu menurunkan rasa cemas itu sendiri. Misalnya, pada siswa laki-laki komponen kecemasan biasanya muncul pada pikirannya, maka mereka pun lebih banyak menggunakan cara-cara seperti pemfokusan pada solusi (problem solving) atau rasionalisasi dan distraksi untuk meredakan kecemasan dalam pikirannya tersebut.

Sedangkan pada siswa perempuan, komponen kecemasan utamanya muncul pada emosinya, maka coping yang dipilih pun berfokus pada bagaimana meredakan perasaan mengganggu yang timbul akibat rasa cemasnya, seperti berdoa. Dengan demikian, dapat dikatakan bahwa teknik coping kecemasan yang adaptif pada siswa-siswi pada penelitian ini, merupakan salah satu penyebab tingkat kecemasan yang dimiliki berada pada tingkat mild atau tingkat rendah.

\section{KESIMPULAN}

Berdasarkan hasil diskusi, dapat ditarik kesimpulan bahwa pada siswa SMA yang memiliki tingkat kecemasan mild atau rendah dalam menghadapi UTBK tahun 2019, kebanyakan memiliki teknik coping kecemasan yang cenderung adaptif. Adapun yang dimaksud dengan adaptif adalah mampu secara baik mengurangi rasa cemas tanpa menghindarinya secara terus menerus. Coping tersebut kebanyakan melibatkan kognitif dimana mereka menggunakan kekuatan pikiran untuk mengatasi pikiran negatif atau perasaan tidak menyenangkan yang dirasakan. Teknik yang dilakukan pun bermacam-macam, seperti problem solving, managing avoidance, challenging anxious thoughts, distraction, dan rationalization. Hal Ini mengindikasikan bahwa umumnya kecemasan pada siswa-siswi ini bersumber pada komponen pikiran, terutama pada siswa laki-laki.

Sedangkan penemuan unik yang didapat pada siswa perempuan adalah ritual religi dengan berdoa sebagai coping kecemasannya. Bentuk coping tersebut dilakukan karena pada siswa perempuan komponen utama kecemasan yang ditemukan bukan berasal dari pikiran, tetapi pada emosi mereka, sehingga teknik tersebut hanya ditemukan pada siswa perempuan, namun tidak pada siswa laki-laki.

\section{REFERENSI}

[1] Damanik, "Cek Hasil SMBPTN 2013 di "Kompas.com" Yuk!," 2013.

[2] InfoSBMPTN, "Siap Menghadapi SBMPTN 2015," 2014.

[3] Belmawa Ristekdikti, "165.831 Peserta Dinyatakan Lulus SBMPTN," 2018.

[4] A. M. Jannah, "Hubungan Antara Efikasi Diri dengan Kecemasan Menghadapi Ujian SBMPTN," Jurnal Ilmiah Psikologi Terapan, 2015.

[5] H. P. Rini, "Self Efficacy denagn Kecemasan dalam Menghadapi Ujian Nasional," Jurnal Online Psikologi, pp. 36-38, 2013.

[6] C. M. Krisnaningrum, "Hubngan Strategi Koping dengan Kecemasan MEnghadapi Ujian SBMPTN," Jurnal Ilmiah Psikologi Terapan, 2015.

[7] A. dan R. Rachmahana, "Hubungan antara Konsep Diri Akademik dengan Kecemasan 
Mwnghadapi Ujian Nasional," pp. 1-18, 2005.

[8] D. Greenberger dan C. Padesky, Mind Over Mood : A Cognitive Therapy Treatment Manual for Clients, New York: The Guildford Press, 1995.

[9] Cambridgeshire and Peterborough, "Coping with Anxiety".

[10] R. J. Thompson, J. Mata, J. M. Susanne, J. Jonides, M. Bushckuehl dan I. H. Gotlib, "Maladaptive Coping, Adaptive Coping, and Depressive Symptoms : Variansions across age and Depressive State," Behavior Research and Therapy, 2010.

[11] American Psychologcal Association, "American Psychological Associtation," October 2016. [Online]. Available: https://www.apa.org/helpcenter/anxiety. [Diakses 8 February 2020].

[12] M. Hamilton, "The Assessment of Anxiety States by Rating," Journal of Medical Psychology, pp. 50-55, 1959.

[13] O. Leedy, Practical Research : Planning and Design, New Jersey: PEarson Education Inc., 2010.
[14] H. Nassaji, "Qualitative and Descriptive Research : Data Type versus Data Analysis," SAGE journals, 2015.

[15] H. L. Dulock, "Research Design : Descriptive Research," Journal of Pediatric Oncology Nursing, pp. 154-157, 1993.

[16] N. E. Thenga, H. N. Mutshaeni dan T. S. Mashau, "Secondary School Learners' Stress Coping Strategies," International Journal of Educational Sciences, pp. 21-27, 2015.

[17] K. I. Pragament, H. G. Koenig dan L. M. Perez, "The Many Methods of Religious Coping : Development and Initial Validation of the RCOPE," Journal of Clinical Psychology, pp. 519-543, 2000.

[18] J. Hunt dan D. Eisenberg, "Mental Health Problems and Help-Seeking Behavior Among College Students," Journal of Adolescent Health, vol. 46, no. 1, pp. 3-10, 2010. 